\title{
Study of Feeding Palm Press Fibre and Sheanut Cake Based Complete Diets on Eating Behaviour and Rumination in Lactating Buffaloes
}

\author{
M. Kishan Kumar* \\ College of Fishery Science, P.V. Narsimha Rao Telangana Veterinary University, Pebbair, \\ Wanaparthy Dist. Telangana State-509104, India \\ *Corresponding author
}

\begin{tabular}{l} 
K e y w o r d s \\
$\begin{array}{l}\text { Sheanut cake, Palm } \\
\text { press fibre, Eating } \\
\text { behaviour, } \\
\text { Rumination, Lactating } \\
\text { buffaloes, Chewing }\end{array}$ \\
\hline Article Info \\
$\begin{array}{l}\text { Accepted: } \\
\text { 24 February } 2018 \\
\text { Available Online: } \\
\text { 10 March } 2018\end{array}$ \\
\hline
\end{tabular}

\section{Introduction}

In many developing countries like India, there is a need to utilize agro-industrial byproducts and crop residues to narrow down the existing gap between availability and requirement of feed stuffs for livestock. Our country presently faces a net deficit of $28 \%$ green fodder, $23.5 \%$
Three experimental rations formulated in the study were conventional diet (RI), and two complete diets (RII and RIII). Two complete diets, processed into mash were formulated using palm press fibre (20\% and 15\%) (PPF) and Chopped Jowar straw (20\% and 25\%) as roughage source and sheanut cake (18.5\% and 28\%) (SNC) (R II and R III) along with locally available concentrate ingredients (roughage: concentrate ratio of 40:60) were compared with conventional ration (RI) (Chopped Jowar Straw, green Jowar fodder and concentrate mixture fed separately) to study the effect of these diets on intake, eating behaviour and rumination of Lactating Murrah buffaloes. Twelve Lactating Murrah buffaloes were randomly allotted to these three diets and fed for a period of 120 days. Feeding of PPF-SNC based complete diets significantly $(\mathrm{P}<0.01)$ higher eating time, percent of time spent for eating and eating time per $\mathrm{kg}$ DMI were observed on conventional ration (RI) than complete diets. Statistical analysis revealed significant (P $<0.01$ ) differences in the number of rumination periods, length of rumination and rumination periods per $\mathrm{kg}$ DMI among the experimental rations. Higher chewing time ( $\mathrm{P}$ $<0.01$ ) was observed with conventional ration than complete diets. Lesser resting time ( $\mathrm{P}$ $<0.01$ ) and percent of time spent for resting and lesser resting time per $\mathrm{kg}$ DMI was observed with conventional ration than complete diets. Eating and Rumination behaviour indicated that eating time, rumination time, rumination period and chewing time were significantly ( $\mathrm{P}<0.01)$ higher, whereas resting time was lower on conventional ration (RI) when compared with complete diets (RII and RIII). The Present study indicated that incorporation of palm press fibre $(15 \%)$ and sheanut cake $(28 \%)$ in complete diet had no adverse effect on eating and rumination behavior of lactating buffaloes. 
ingredients as protein and roughage source, respectively. Sheanut cake a solid residue of sheanuts, could be a potential ingredient available in West Africa (Dei et al., 2007).

In the present study, an attempt was made to utilize palm press fibre and sheanut cake at different levels along with other locally available concentrate ingredients in complete diets for lactating Murrah buffaloes to assess the effect of these complete diets on intake, eating behaviour and rumination of lactating buffaloes.

\section{Materials and Methods}

Two complete diets (roughage concentration ratio, 40:60) were formulated with $\mathrm{SNC}$ as concentrate ingredient and PPF as roughage component being incorporated at $18.5 \%$ and $20.0 \%$ (R II) and 28.0 and $15.0 \%$ (R III) level. The other roughage used was chopped jowar stover. The complete diets (R II and R III) were compared with conventional ration (R I) consisting of chopped jowar stover, Jowar green and concentrate mixture. The ingredient composition of concentrate mixture and complete diets has been shown in Table 3 .

Twelve lactating graded murrah buffaloes (3-4 lactations) of uniform milk yield and in their early stage of lactations were distributed randomly into three groups of four animals each in a complete randomized design. The animals were housed in a well-ventilated conventional stall barn maintained in hygienic conditions and stall fed with the respective diets throughout the experimental period of 120 days. A 7 day digestion trial was conducted at the end of the experiment to assess the effect of these complete diets on intake, eating behaviour and rumination of lactating buffaloes.

The complete diets were offered twice daily ad libitum, while in conventional group, the roughages and concentrates were offered separately to meet the maintenance and production requirements of milch buffaloes (ICAR, 1998).

Eating time was defined as time spent for ingestion of feed with the help of lips, teeth and tongue into mouth. Time spent for regurgitation of the swallowed feed through chewing and finally swallowing was considered as the rumination time (Wilson and Brigstocke, 1981). A period of rumination was defined as at least 5 minutes of ruminating activity, followed by at least 5 minutes without ruminating activity. Total time spent for chewing was calculated as the total time spent for eating and ruminating. Total time spent for resting was calculated as total time monitored the animal for observing the behaviour minus time spent for chewing (Maekawa et al., 2002b).

Eating and ruminating behaviour of all lactating buffaloes fed on three experimental rations ( $\mathrm{R}$ I, R II and R III) was monitored visually for a period of 8 hours in a day (4h period immediately after each feeding). Eating and ruminating activities were noted every 5 minutes and each activity was assumed to persist for the entire 5 minutes interval. To estimate time spent for eating or ruminating per kilogram of DM intake, the average intake for the total time monitored the animal (8h) for observing the behaviour was used.

\section{Results and Discussion}

The chemical composition of complete diets, concentrate mixture, Sheanut cake and Palm press fibre on DM basis is given in Table 1. Average $\mathrm{CP}$ and $\mathrm{CF}$ of complete diets was $12.2 \%$ and $24 \%$ respectively.

The mean DMI values (Table 2) were 6.07 \pm $0.03,6.27 \pm 0.09$ and $5.90 \pm 0.23 \mathrm{~kg}$ during 480 minutes of behavioural observation, for 
experimental animals fed with rations I, II and III, respectively. Statistical analysis revealed no significant difference among the rations (Table 2).

The mean eating time was $100.82 \pm 0.86$, $94.50 \pm 0.36$ and $90.61 \pm 1.88$ minutes in lactating buffaloes fed with rations I, II and III respectively, during 480 minutes of behavioural observation (Table 2).

The buffaloes spent an average $21.01 \pm 0.18$, $19.69 \pm 0.08$ and $18.88 \pm 0.39$ percent of time towards eating the feed and the mean values for eating time per $\mathrm{kg}$ DMI were $16.62 \pm 0.06$, $15.09 \pm 0.22$ and $15.42 \pm 0.35$ minutes in groups I, II and III, respectively.

Significantly $(\mathrm{P}<0.01)$ higher eating time, percent of time spent for eating and eating time per $\mathrm{kg}$ DMI was observed with conventional ration than complete diets (Table 2).

The buffaloes spent an average $213.50 \pm 1.58$, $178.93 \pm 0.82$ and $179.43 \pm 1.85$ minutes and $44.48 \pm 0.33,37.28 \pm 0.17$ and $37.38 \pm 0.38$ percent of time towards rumination in groups I, II and III, respectively. The mean values for rumination time per $\mathrm{kg}$ DMI were $35.21 \pm$ $0.14,21.88 \pm 0.32$ and $23.39 \pm 0.97$ minutes, in groups I, II and III respectively (Table 2). Statistical analysis revealed significantly $(\mathrm{P}<0.01)$ higher rumination time, percent of time spent for rumination and rumination time per kg DMI with conventional ration than complete diets.

The mean values for number of rumination periods were $8.57 \pm 0.06,6.07 \pm 0.12$ and 6.64 \pm 0.26 and the length of rumination was 24.99 $\pm 0.09,29.77 \pm 0.68$ and $27.42 \pm 0.82$ minutes, for groups fed with rations I, II and III, respectively (Table 2). The number of rumination periods per $\mathrm{kg}$ DMI were $1.42 \pm$ $0.01,0.97 \pm 0.03$ and $1.15 \pm 0.09$, respectively. Statistical analysis revealed significant $(\mathrm{P}<0.01)$ differences in the number of rumination periods, length of ruminations and rumination periods per $\mathrm{kg}$ DMI among the experimental rations (Table 2).

Three groups of buffaloes spent an average $314.3 \pm 2.38,273.4 \pm 1.17$ and $270.0 \pm 1.06$ minutes of time respectively towards chewing (Table 2). Significantly $(\mathrm{P}<0.01)$ higher chewing time was observed with conventional ration than complete diets.

Resting time was $165.68 \pm 2.38,206.56 \pm 1.17$ and $209.96 \pm 1.06$ minutes in buffaloes fed with experimental rations I, II and III, respectively during 480 minutes of behavioural observation (Table 2).

The buffaloes spent an average $34.5 \pm 0.50$, $43.40 \pm 0.24$ and $43.74 \pm 0.22$ percent of time towards resting and the mean values for resting time per $\mathrm{kg}$ DMI were $27.34 \pm 0.53$, $33.00 \pm 0.55$ and $35.84 \pm 1.52$ minutes in groups I, II and III, respectively. Significantly $(\mathrm{P}<0.01)$ lesser resting time and per cent of time spent for resting and lesser resting time per $\mathrm{kg}$ DMI was observed with conventional ration than complete diets.

Eating and rumination behaviour of all lactating buffaloes fed on three experimental rations ( $\mathrm{R}$ I, R II and $\mathrm{R}$ III) in the present study was monitored visually for a period of 8 hours (480 minutes) in a day (4-h period immediately after each feeding).

There was no significant difference in the DMI values among the experimental rations (R I, R II and R III) in lactating buffaloes (Table 2) during behavioural study period (8h). Maekawa et al., (2002a, b) reported a non-significant difference in DMI of lactating Holstein cows fed on total mixed rations (TMR) containing 40:60, 50:50 and 60:40 forage to concentrate ratio. 
Table.1 Chemical composition of experimental rations (\%DM) fed to lactating buffaloes

\begin{tabular}{|c|c|c|c|c|c|c|c|}
\hline \multirow[b]{2}{*}{ Nutrient } & \multicolumn{2}{|c|}{ Complete diet } & \multicolumn{3}{|c|}{ Ration I (Control) } & \multirow[b]{2}{*}{ Sheanut cake } & \multirow{2}{*}{$\begin{array}{l}\text { Palm press } \\
\text { fiber }\end{array}$} \\
\hline & $\begin{array}{l}\text { Ration II } \\
\quad \text { (Mash I) }\end{array}$ & $\begin{array}{r}\text { Ration III } \\
\text { (Mash II) }\end{array}$ & $\begin{array}{l}\text { Concentrate } \\
\text { mixture }\end{array}$ & $\begin{array}{c}\text { Chopped } \\
\text { jowar straw }\end{array}$ & $\begin{array}{l}\text { Jowar } \\
\text { green } \\
\text { fodder }\end{array}$ & & \\
\hline \multicolumn{8}{|c|}{ Proximate principle } \\
\hline Dry matter & 89.27 & 89.44 & 93.69 & 91.88 & 24.92 & 93.26 & 89.22 \\
\hline Organic matter & 92.78 & 93.48 & 91.32 & 88.24 & 91.74 & 92.19 & 90.76 \\
\hline Crude protein & 12.12 & 12.30 & 17.94 & 3.46 & 7.18 & 13.21 & 8.28 \\
\hline Crude fibre & 23.84 & 24.22 & 9.56 & 30.12 & 28.02 & 9.82 & 38.74 \\
\hline Ether extract & 1.50 & 1.79 & 5.34 & 1.11 & 1.24 & 2.12 & 9.16 \\
\hline NFE & 55.32 & 55.17 & 58.48 & 53.55 & 55.30 & 67.04 & 34.58 \\
\hline Total ash & 7.22 & 6.52 & 8.68 & 11.76 & 8.26 & 7.81 & 9.24 \\
\hline \multicolumn{8}{|c|}{ Cell wall constituent } \\
\hline NDF & 59.92 & 56.20 & 33.26 & 70.20 & 66.48 & 60.27 & 72.14 \\
\hline$\overline{\mathbf{A D F}}$ & 46.62 & 46.92 & 17.22 & 50.70 & 46.31 & 41.13 & 53.12 \\
\hline Hemicellulose & 13.30 & 9.28 & 16.04 & 19.50 & 20.17 & 19.14 & 19.02 \\
\hline Cellulose & 18.41 & 15.93 & 13.28 & 42.12 & 33.52 & 7.22 & 33.28 \\
\hline \multicolumn{8}{|l|}{ Mineral } \\
\hline $\mathrm{Ca}$ & 0.96 & 1.12 & 1.08 & 0.64 & 0.74 & 1.16 & 0.62 \\
\hline$\overline{\mathbf{P}}$ & 0.68 & 0.72 & 0.82 & 0.38 & 0.18 & 0.22 & 0.21 \\
\hline
\end{tabular}


Table.2 Eating and rumination behaviour in lactating graded Murrah buffaloes under different experimental rations

\begin{tabular}{|c|c|c|c|c|c|c|c|c|c|c|c|c|c|c|c|}
\hline & \multirow{2}{*}{$\begin{array}{l}\text { Animal } \\
\text { No. }\end{array}$} & \multirow{2}{*}{$\begin{array}{l}\text { DMI } \\
\text { (kg/ } \\
\text { 8hrs) }\end{array}$} & \multicolumn{3}{|c|}{ Eating time } & \multicolumn{3}{|c|}{ Rumination time } & \multicolumn{3}{|c|}{ Rumination period } & \multirow{2}{*}{$\begin{array}{l}\text { Chewing } \\
\text { time (Min.) }\end{array}$} & \multicolumn{3}{|c|}{ Resting time } \\
\hline & & & Min. & $\begin{array}{l}\% \text { of time } \\
\text { spent }\end{array}$ & $\begin{array}{l}\text { Min./kg } \\
\text { DMI }\end{array}$ & Min. & $\begin{array}{l}\% \text { of time } \\
\text { spent }\end{array}$ & $\begin{array}{l}\text { Min./kg } \\
\text { DMI }\end{array}$ & No. & $\begin{array}{l}\text { Length } \\
\text { (Min.) }\end{array}$ & $\begin{array}{l}\text { No./ kg } \\
\text { DMI }\end{array}$ & & Min. & $\begin{array}{l}\% \text { of time } \\
\text { spent }\end{array}$ & $\begin{array}{l}\text { Min./kg } \\
\text { DMI }\end{array}$ \\
\hline \multicolumn{16}{|c|}{ Conventional ration (Ration I) } \\
\hline Control & 457 & 5.98 & 98.86 & 20.60 & 16.52 & 211.14 & 43.99 & 35.29 & 8.57 & 24.73 & 1.44 & 310.00 & 170.00 & 35.42 & 28.46 \\
\hline Control & 430 & 6.06 & 100.43 & 20.92 & 16.58 & 210.86 & 43.93 & 34.81 & 8.43 & 25.09 & 1.39 & 311.28 & 168.71 & 35.15 & 27.86 \\
\hline Control & 408 & 6.09 & 101.00 & 21.04 & 16.59 & 214.43 & 44.67 & 35.23 & 8.57 & 25.10 & 1.41 & 315.43 & 164.57 & 34.29 & 27.04 \\
\hline Control & 409 & 6.13 & 103.00 & 21.46 & 16.80 & 217.57 & 45.33 & 35.49 & 8.71 & 25.04 & 1.42 & 320.57 & 159.43 & 33.21 & 26.01 \\
\hline Mean & & 6.07 & $100.82^{b}$ & $21.01^{b}$ & $16.62^{b}$ & $213.50^{b}$ & $44.48^{b}$ & $35.21^{\mathrm{b}}$ & $8.57^{\mathrm{c}}$ & $24.99^{\mathrm{a}}$ & $1.42^{\mathrm{c}}$ & $314.32^{b}$ & $165.68^{\mathrm{a}}$ & $34.52^{\mathrm{a}}$ & $27.34^{\mathrm{a}}$ \\
\hline$\pm \mathbf{S E}$ & & 0.03 & 0.86 & 0.18 & 0.06 & 1.58 & 0.33 & 0.14 & 0.06 & 0.09 & 0.01 & 2.38 & 2.38 & 0.50 & 0.53 \\
\hline \multicolumn{16}{|c|}{ Complete diet -Mash I (Ration II) } \\
\hline Mash & 357 & 6.04 & 94.57 & 19.70 & 15.68 & 178.71 & 37.23 & 22.72 & 6.00 & 30.02 & 1.00 & 273.29 & 206.71 & 43.07 & 34.28 \\
\hline Mash & 458 & 6.45 & 95.43 & 19.88 & 14.80 & 181.00 & 37.71 & 21.26 & 5.86 & 31.30 & 0.91 & 276.43 & 203.57 & 42.41 & 31.60 \\
\hline Mash & 473 & 6.23 & 94.29 & 19.64 & 15.15 & 179.00 & 37.29 & 22.01 & 6.43 & 28.01 & 1.03 & 273.29 & 206.71 & 43.07 & 33.22 \\
\hline Mash & 432 & 6.37 & 93.71 & 19.52 & 14.72 & 177.00 & 36.88 & 21.52 & 6.00 & 29.73 & 0.94 & 270.71 & 209.29 & 43.6 & 32.88 \\
\hline Mean & & 6.27 & $94.50^{\mathrm{a}}$ & $19.69^{\mathrm{a}}$ & $15.09^{\mathrm{a}}$ & $178.93^{a}$ & $37.28^{\mathrm{a}}$ & $21.88^{\mathrm{a}}$ & $6.07^{\mathrm{a}}$ & $29.77^{c}$ & $0.97^{\mathrm{a}}$ & $273.43^{\mathrm{a}}$ & $206.57^{b}$ & $43.04^{b}$ & $33.00^{\mathrm{a}}$ \\
\hline$\pm \mathrm{SE}$ & & 0.09 & 0.36 & 0.08 & 0.22 & 0.82 & 0.17 & 0.32 & 0.12 & 0.68 & 0.03 & 1.17 & 1.17 & 0.24 & 0.55 \\
\hline \multicolumn{16}{|c|}{ Complete diet -Mash II (Ration III) } \\
\hline Mash & 381 & 6.11 & 92.43 & 19.26 & 15.16 & 180.43 & 37.59 & 22.5 & 6.57 & 27.76 & 1.09 & 272.86 & 207.14 & 43.15 & 34.03 \\
\hline Mash & 464 & 5.92 & 92.86 & 19.35 & 15.73 & 177.43 & 36.96 & 23.21 & 6.71 & 26.67 & 1.14 & 270.29 & 209.71 & 43.69 & 35.50 \\
\hline Mash & 462 & 5.26 & 85.00 & 17.71 & 16.19 & 184.14 & 38.36 & 26.15 & 7.29 & 25.72 & 1.40 & 269.14 & 210.86 & 43.93 & 40.25 \\
\hline Mash & 397 & 6.32 & 92.14 & 19.20 & 14.58 & 175.71 & 36.61 & 21.69 & 6.00 & 29.53 & 0.95 & 267.86 & 212.14 & 44.196 & 33.59 \\
\hline Mean & & 5.90 & $90.61^{a}$ & $18.88^{\mathrm{a}}$ & $15.42^{\mathrm{a}}$ & $179.43^{a}$ & $\mathbf{3 7 . 3 8}^{\mathrm{a}}$ & $23.39^{\mathrm{a}}$ & $6.64^{b}$ & $27.42^{b}$ & $1.15^{b}$ & $270.04^{a}$ & $209.96^{b}$ & $43.74^{b}$ & $35.84^{\mathrm{b}}$ \\
\hline$\pm \mathbf{S E}$ & & 0.23 & 1.88 & 0.39 & 0.35 & 1.85 & 0.38 & 0.97 & 0.26 & 0.82 & 0.09 & 1.06 & 1.06 & 0.22 & 1.52 \\
\hline
\end{tabular}

Means with different superscripts in a column differ significantly $(\mathrm{P}<0.01)$ 
Table.3 Ingredients composition of experimental diets

\begin{tabular}{|l|c|c|c|}
\hline Ingredient & $\begin{array}{l}\text { Concentrate } \\
\text { mixture (R I) }\end{array}$ & (R II) & Complete diets \\
\hline Chopped jowar straw (kutti) & - & 20.00 & 25.00 \\
\hline Palm press fibre & - & 20.00 & 15.00 \\
\hline Maize & 30.0 & 10.00 & 10.00 \\
\hline Deoiled rice bran & 17.0 & 10.50 & 4.00 \\
\hline Wheat bran & 20.0 & 9.00 & 5.00 \\
\hline Groundnut cake & 15.0 & 9.00 & 10.00 \\
\hline Cottonseed cake & 15.0 & - & - \\
\hline Sheanut cake & - & 18.50 & 28.00 \\
\hline Salt & 1.00 & 1.00 & 1.00 \\
\hline Mineral mixture & 2.00 & 2.00 & 2.00 \\
\hline Vitamin $\mathbf{A D}_{3}(\mathbf{g} / \mathbf{q})$ & 20.0 & 10.0 & 10.0 \\
\hline
\end{tabular}

The apparently higher intake on complete diet mash (R II) in the present study could be due to smaller particle size and variation in ingredient and chemical composition and the feed was eaten faster thus resulting in larger meal. Putnam et al., (1966) observed higher feed intake as the feed particle size decreased. Higher DMI due to larger meal was also reported earlier by Metz (1975) and Vasilatos et al., (1980). Variation in DMI due to chemical composition and physical form of the diet was reported by Dado and Allen (1994).

Significantly $(\mathrm{P}<0.01)$ higher eating time, per cent of time spent for eating and eating time per kg DMI were observed on conventional ration (R I) than complete diets (R II and $\mathrm{R}$ III) in lactating buffaloes (Table 2). In the present study eating time was less with complete diets in mash form as compared to conventional diet in lactating buffaloes.

The rumination time, percent of time spent for rumination and rumination time per $\mathrm{kg}$ DMI were significantly $(\mathrm{P}<0.01)$ higher on conventional ration ( $\mathrm{R} \mathrm{I}$ ) than complete diets (R II and R III) in lactating buffaloes (Table 2). These results were in agreement with
Maekawa et al., (2002a, b) who observed linear increase in rumination time with increasing proportion of silage as fibre in the TMR of lactating Holstein cows. Rumination time further depends on the ease of comminuting fibrous particles and on the physical properties of the fibre like length (Santini et al., 1983; Woodford and Murphy, 1988), specific fragility (Chai et al., 1988) and specific gravity (Des Bordes and Welch, 1984). Maekawa et al., (2002a, b) reported that rumination time depends on the type of diet. The data of behavioural study indicated the difference in the type of diet with conventional as an important factor for higher rumination time, percent time spent on rumination and rumination time per $\mathrm{kg}$ DMI when compared with two complete diets which were in mash form.

Significantly $(\mathrm{P}<0.01)$ higher total number of rumination periods and rumination periods per kg DMI were observed on conventional ration (R I) followed by complete diets ( $(\mathrm{R}$ III) and (R II) in lactating buffaloes (Table 2). But the length of rumination period ( $\mathrm{min}$ ) was significantly $(\mathrm{P}<0.01)$ higher $(29.77 \mathrm{~min})$ on complete diet (R II) when compared with complete diet RIII (27.42 min) and control 
ration RI (24.99 min). Bosch et al., (1986) found a shorter ruminating period per $\mathrm{kg}$ DMI when changing from restricted to ad lib feeding of lactating cows receiving herbage products. Physical properties of the fibre play a role in the separation and differential clearance of particles from the reticulorumen which affects rumination period (Sutherland, 1987). The more number of rumination periods, more length of rumination period and rumination periods per $\mathrm{kg}$ DMI with conventional ration in the present study might be attributed character and staple length of forage as compared to mash form of complete diets.

Significantly $(\mathrm{P}<0.01)$ higher chewing time was observed on conventional ration (R I) than complete diets ( $\mathrm{R}$ II and R III) in lactating buffaloes (Table 2). This could be due to higher level of succulent green fodder in the conventional ration, which resulted in higher eating, rumination and chewing time in order to increase DMI and to degrade fibre into smaller particles. Woodford et al., (1986), Lu (1987) and Woodford and Murphy (1988) have determined chewing activity on different feedstuffs and rations intending to develop a roughage value system. Coulon et al., (1987) concluded that cows increase their ingestion either by extending chewing time (during eating and/or ruminating) if the latter initially is short or by forcing up chewing rate when the corresponding duration is long. More chewing time with conventional ration in the present study compared to mash form of complete diets may be attributed to type and nature of diet.

Significantly $(\mathrm{P}<0.01)$ higher total resting time (min) and per cent of time spent for resting was observed on complete diets (R II and $\mathrm{R}$ III) than conventional ration (R I) in lactating buffaloes (Table 2). This could be due to lower eating, ruminating and chewing time on complete diets. Similar results were also observed by Maekawa et al., (2002a,b) in multiparous and primiparous lactating cows when fed one of four diets (three TMR containing 40,50 or $60 \%$ silage and a separate ingredient diet containing 50\% concentrate). There was a significant $(\mathrm{P}<0.01)$ increase in resting time per $\mathrm{kg}$ DMI on complete diet R III than conventional ration (R I) in lactating buffaloes.

Eating and rumination behaviour indicated that eating time, rumination time, rumination period and chewing time were significantly $(\mathrm{P}<0.01)$ higher, whereas resting time was lower on conventional ration (RI) when compared with complete diets (R II and R III) in lactating buffaloes. The Present study indicated that incorporation of palm press fibre $(15 \%)$ and sheanut cake $(28 \%)$ in complete diet had no adverse effect on eating and rumination behaviour of lactating buffaloes.

\section{References}

Bosch M W, Kamphuis F W, Ploeger H W and Veth P 1986 De relaties tussen ruwvoederopname, herkauwaktiviteit en penslediging bij koeien Devakgroepen Veevoeding en Dierfysiologie Wageningen, 49pp.

Chai K, Milligan L P, and Mathison G W 1988 Effect of muzzling on rumination in sheep. Canadian Journal of Animal Science. 68: 387-397.

Coulon J B, Doreau M, Remond B and Journet M 1987 Evolution des activites alimentaires des vaches laitieres en debut de lactation et liaisonavec les quantities d'aliments ingerees Reprod Nutr Develop., 27: 67-75

Dado R G and Allen M S 1994 Variation in and relationships among feeding, chewing and drinking variables for lactating dairy cows. Journal of Dairy Science, 77: 132144. 
Dei, H.K., S.P. Rose, and A.M. Mackenzie. 2007. Sheanut (Vitellaria paradoxa) meal as a feed ingredient for poultry. Worlds Poult. Sci. J. 63:611-624.

DesBordes C K and Welch J G 1984 Influence of specific gravity on rumination and passage of indigestible particles. Journal of Animal Science, 59: 470-475.

ICAR, 1998. Nutrient Requirements of Livestock and Poultry. Indian Council of Agricultural Research, New Delhi, India.

ICAR, 2013. Nutrient requirements of Cattle and Buffalo. Indian Council of Agricultural Research, New Delhi, India.

Lu C D 1987 Implication of forage particle length on chewing activities and milk production in dairy goats Journal of Dairy Science 70: 1411-1416.

Maekawa M, Beauchemin K A and Christensen D A 2002b Chewing activity, saliva production and ruminal $\mathrm{pH}$ of primiparous and multiparous lactating dairy cows. Journal of Dairy Science 85: 1176-1182.

Maekawa M, Beauchemin K A and Christensen D A 2002a Effect of concentrate level and feeding management on chewing activities, saliva production and ruminal $\mathrm{pH}$ of lactating dairy cows. Journal of Dairy Science 85: 1165-1175.

Metz J H M 1975 Time patterns of feeding and rumination in domestic cattle Meded Landbouwhoogesch, Wageningen 75: 1227.

Nagalakshmi, D, Nalini Kumari, N. and Srinivasa Rao, D. 2010. Feed processing. Effect on nutrient availability. In: Proc. Animal Nutrition Strategies for Environment Production and Poverty Alleviation" held at College of
Veterinary Science \& Animal Husbandry, Bhubaneswar, Odisha, India. pp 76-83.

Putnam P A, Lehmann R and Davis R E 1966 Feed intake and salivary secretion by steers. Journal of Animal Science, 25: 817-820.

Santini F J, Hardie A R, Jorgensen N A and Finner M F 1983 Proposed use of adjusted intake based on forage particle length for calculation of roughage indexes Journal of Dairy Science, 66: 811- 820.

Sutherland T M 1987 Particle seperation in the forestomachs of sheep pp 43-73 In; Aspects of digestive physiology in ruminants (ed a Dobson and M J Dobson) Comstock Publishing Association, Ithaca, New York.

Vasilatos Regina and Wangsness, J. Paul.1980 Feeding behaviour of lactating dairy cows measured by time-lapse photography. Journal of Dairy Science, 63: 412-416.

Welch J G and Smith A M 1969 Influence of forage quality on rumination time in sheep. Journal of Animal Science 28: 813-818.

Wilson P N and Brigstocke T D A 1981. Improved feeding of cattle and sheep $\left(1^{\text {st }}\right.$ edition). Granada publishing Ltd, London.

Woodford J A, Jorgensen M A and Barrington G P 1986 Impact of dietary fibre and physical form on performance of lactating dairy cows. Journal of Dairy Science 69: 1035-1047.

Woodford S T and Murphy M R 1988 Effect of forage physical form on chewing activity, dry matter intake and rumen function of dairy cows in early lactation. Journal of Dairy Science 71: 674-686.

\section{How to cite this article:}

Kishan Kumar, M. 2018. Study of Feeding Palm Press Fibre and Sheanut Cake Based Complete Diets on Eating Behaviour and Rumination in Lactating Buffaloes. Int.J.Curr.Microbiol.App.Sci. 7(03): 2690-2697. doi: https://doi.org/10.20546/ijcmas.2018.703.311 